Protestantismo em Revista é licenciada sob uma Licença Creative Commons.

http://dx.doi.org/10.22351/nepp.v43i01.2992

\title{
A educação integral correlacionada aos princípios educacionais na cosmovisão cristã: tensões e rupturas
}

\author{
Integral education correlated with educational principles in christian worldview: tensions \\ and ruptures
}

\section{Daniel Barros de Lima* Laude Erandi Brandenburg**}

\begin{abstract}
Resumo
Este estudo trata de modo introdutório da educação integral, da perspectiva da educação sob a cosmovisão cristã. Os pressupostos teóricos acerca de uma educação que comtemple o ser humano como um todo podem ser correlacionados aos princípios norteadores da educação cristã quando esta se propõe em fornecedor subsídios de uma visão de mundo que contemple todas as dimensões do ser humano como possíveis de serem observadas pelas Escrituras Sagradas. Sabe-se que nem sempre a igreja considerou essa assertiva, em especial o movimento pentecostal em sua gênese preocupou-se com o ensino de suas doutrinas como suficientes para seus membros. Dessa forma, busca-se compreender uma educação integral como possível de ser aplicada pela igreja do século XXI em um discurso de fé que seja simultaneamente transcendente e imanente.
\end{abstract}

\section{Palavras-chave}

Educação Integral. Cosmovisão Cristã. Missão.

\begin{abstract}
This study deals in an introductory way of integral education, from the perspective of education under a Christian worldview. The theoretical assumptions about an education that serves as a human being as a whole can be correlated with guiding principles of Christian education when it is proposed in the provider subsidies of a world view that contemplates all as dimensions of the human being as possible to be observed by Holy Scriptures. It is known that a church does not always consider this assertive, especially the Pentecostal movement in its general concern with teaching its doctrines as sufficient for its members. In this way, we seek a
\end{abstract}

[Texto recebido em março de 2017 e aceito em junho de 2017, com base na avaliação cega por pares realizada por pareceristas ad hoc]

* Licenciado em História. Especialista em Metodologia do Ensino Superior. Bacharel em Ciências Teológicas. Mestre em História Social. Doutorando em Teologia (DINTER pelo PPG-EST). Docente da Faculdade Boas Novas. E-mail: daniel.barros@fbnovas.edu.br

** Graduada em Pedagogia (Universidade do Vale do Rio dos Sinos). Doutora em Teologia (Escola Superior de Teologia). Docente do Bacharelado em Teologia e da Licenciatura em Música (Faculdades EST). Email: laude@est.edu.br 
comprehensive education as possible to be applied by the 21st century church in a discourse of faith that is both transcendent and immanent.

Keywords

Integral Education. Christian Worldview. Mission.

\section{Introdução}

Este breve estudo propõe uma articulação com os pressupostos da educação integral enquanto tendência pedagógica no campo da educação e os princípios da cosmovisão cristã, mais precisamente quando se pensa a educação cristã de modo holístico no sentido de compreender o ser humano como um todo em suas múltiplas dimensões.

Nas últimas décadas, educadores e educadoras têm refletido sua práxis educacional e desenvolvido pesquisas em torno da educação integral como um paradigma necessário a ser reexaminado e imprescindível a ser praticado em todos os níveis educacionais. A despeito de quaisquer deficiências a proposta de uma educação integral passa pelo desenvolvimento de estudos que apresentem os benefícios que uma educação que comtemple o ser humano como um todo possa trazer ao próprio melhoramento da educação brasileira.

Nesse sentido, a igreja enquanto agência educadora é também levada a refletir sobre sua práxis educacional e se tratando de educação cristã, teólogos e pedagogos cristãos têm desenvolvido estudos acadêmicos articulando saberes da educação integral à perspectiva cristã de ensino. O objetivo é contribuir e possibilitar à igreja a reflexão de sua práxis apontando os caminhos de melhoramentos para que seu discurso de fé esteja alinhado com seu engajamento imanente de transformar as pessoas, de poder ser evidentemente sal e $l u z$ do mundo. Assim, os estudos de cosmovisão cristã servem de apoio para possibilitar um novo olhar sobre a educação integral.

\section{Educação integral: breve conceituação}

Essas múltiplas dimensões devem ser compreendidas a partir da abordagem do "homem como um 'ser total', preconizando uma educação que integre suas múltiplas dimensões (intelectual, afetiva, física e moral)" ${ }^{1}$ Tiago Camargo observa esse fenômeno educacional em caráter multidimensional expandindo-o às dimensões cognitiva, emocional, psicológica, social, cultural e espiritual em um todo indissociável, indivisível e unitário. Nota-se que o autor considera a espiritualidade ${ }^{2}$ como uma dimensão legítima e

VV.AA. Tendências para a educação integral. São Paulo: Fundação Itaú Social - CENPEC, 2011. p. 19.

2 De acordo com o conceito exposto por Thiago Camargo "a dimensão espiritual, transcendente, ou transpessoal, remete às experiências intra-útero, alcançando as existências passadas do ser, que é préexistente ao corpo biológico e sobrevivente a ele, superando a morte física. A espiritualidade é o encontro e reconhecimento do 'ser maior' em nós e nos outros. Encontro consigo mesmo. Autoconhecimento e conhecimento dos outros. Vida plena interior e ação exterior fraterna e solidária. CAMARGO, Thiago 
participante da integralidade do ser humano. ${ }^{3}$ Algo que, acredita-se, deve ser ainda mais propagado e desenvolvido na esfera acadêmica (a dimensão espiritual).

Observando os adjetivos que definem a educação integral do ser humano indagase acerca da própria natureza da educação: deveria haver uma educação que não contemple tais dimensões de modo que seja distinguida por outros adjetivos que não aqueles supracitados?

Obviamente tal indagação retórica indica que todo constructo de educação deveria contemplar a integralidade do ser humano, e o motivo da ênfase dada ao termo educação integral deve ser por que tais constructos e teorias educacionais falham em observar as múltiplas dimensões do ser humano enfocando uma ou mais dimensões em detrimento de outras. De todo o modo, torna-se imprescindível para cada educador e educadora a busca da coerência do seu discurso por uma educação integral aliada ao desenvolvimento de sua práxis.

Não se pretende, neste estudo, aprofundar as questões próprias da educação integral, mas, basicamente pontuar alguns tópicos. Pode-se lembrar de uma oportuna observação de Rafael Yus quando trata a chamada fragmentação das esferas da vida como um dos motivos que impediram ou ainda impedem o desenvolvimento de uma educação integral, a qual também chama de holística. Yus afirma que os educadores holísticos partem da convicção da existência de uma fragmentação de todas as esferas da vida humana. Nesse sentido, lembra que J. Miller considerava a revolução industrial como o marco histórico em que a humanidade começaria a compartimentalizar e padronizar tudo. O resultado disso foi a própria fragmentação ${ }^{4}$ da vida. ${ }^{5}$

Mais adiante Rafael Yus ratifica esta ideia afirmando que:

Essa fragmentação ultrapassa os muros das escolas e exige delas sua reprodução. Devido a isso, nossas escolas transpiram fragmentação por todos os poros: organização (tempos, espaços) compartimentada e hierarquizada, profissionais especializados e desconectados, conhecimento fragmentado em disciplinas, unidades e lições isoladas, sem possibilidade de ver a relação dentre e entre elas, e entre estas e a realidade que os alunos vivem. Tudo isso prepara e educa para a fragmentação. E precisamente dentro dessa fragmentação que a educação holística pretende restabelecer as conexões em todas as esferas da vida. ${ }^{6}$

Dutra de. Educação integral e espiritualidade: os benefícios dessa relação para a formação integral do ser humano. Porto Alegre: EDUFRGS, 2015. p. 8.

3 CAMARGO, 2015, p. 2.

4 Conforme Rafael Yus, essa fragmentação afeta tudo: vida econômica; vida social; vida pessoal, vida cultural. Dessa forma, ela ultrapassa os muros das escolas e exige delas sua reprodução. YUS, Rafael. Educação integral: uma educação holística para o século XXI. Porto Alegre: Artmed, 2002. p. 13-14.

5 YUS, 2002, p. 13.

6 YUS, 2002, p. 15. 
Se esta condição está posta e até mesmo cristalizada no modus operandi do mundo ocidental, pois esta fragmentação foi constituída pelo pensamento cartesiano que ainda permeia a cultura do Ocidente, o educador e a educadora devem tomar consciência dela e empreender sob a perspectiva holística da educação as habilidades necessárias para transformar as relações educacionais onde e como for necessário.

\section{A integralidade na educação cristã: tensões e rupturas}

Articulando essa percepção ao papel do educador cristão, pode-se de início falar da teologia cristã e seus desafios na história do cristianismo no desenvolvimento do século XX em que a igreja cristã passou a estar mais atenta a novos contornos históricos da modernidade, como por exemplo, as demandas próprias do cenário pós-guerra, em que muitos pensadores cristãos tiveram que repensar o discurso da igreja. Um desses pensadores, em pleno curso da II Guerra Mundial, foi o teólogo Dietrich Bonhoeffer. Em seus escritos teológicos, demonstrou que a igreja poderia estar perdendo a centralidade de seu discurso e por assim dizer perdendo o horizonte de sua mensagem.

Mas, para além da "perca do centro" e da "perca do horizonte", a teologia de Dietrich Bonhoeffer carregou um motivo central que ficou muito bem expresso na máxima: "esta é a questão: Cristo e o mundo que se tornou adulto". ${ }^{7}$ Bonhoeffer se situa além do compromisso e contraposição enfrentando o problema do confronto da fé cristã e a nova realidade do mundo tornado adulto. Dessa forma, torna-se impossível apresentar uma fé dissociada da realidade das pessoas, mais do que isso, dissociada de todas as dimensões que integram o ser humano.

Algumas décadas depois de Dietrich Bonhoeffer escrever sua teologia, mais precisamente no ano de 1974, líderes procedentes de mais de 150 nações se reuniram em Lausanne na Suíca e estabeleceram o que ficou conhecido como Pacto de Lausanne. Este pacto prefigura um documento elaborado por estes líderes, mais de quatro mil ao todo, que sintetiza resoluções imprescindíveis que as igrejas, predominantemente as evangélicas, deveriam empreender para tornar sua missão mais eficiente no mundo. É composto por quinze tópicos que expressam uma responsabilidade cristã engajada num discurso de fé alinhado a uma práxis transformadora no mundo social.

O pacto abrange muitas demandas, outrora negligenciadas pela igreja, desde a sua reflexão sobre o Evangelho e seu conteúdo, até a sua necessária participação política, sua responsabilidade social e educacional. Em suma, uma frase que sintetiza bem o pacto é esta: "o Evangelho todo, para todo homem, para o homem todo". ${ }^{8}$ Obviamente esta última parte

7 GIBELLINI, Rosino. A teologia do Século XX. São Paulo: Loyola, 2012. p. 106.

8 PACTO DE LAUSANNE. Disponível em: <http://www.lausanne.org/pt-br/>. Acesso em: 08 jul. 2015. 
da sentença significa pensar o homem para além do ser espiritual, em suas múltiplas dimensões, como a cognitiva, emocional, psicológica, biológica, física, social, cultural. ${ }^{9}$

O conhecido pesquisador e antropólogo Clifford Geertz criticou certo tipo de pesquisa que era produzida por alguns historiadores e pesquisadores no campo das ciências humanas, a qual consistia em análises de cunho puramente cultural, dissociando a cultura de outros fatores importantes da vida. Geertz afirmava que "o perigo da análise cultural era perder contato com as superfícies duras da vida, como as estruturas políticas e econômicas". ${ }^{10}$

Essa análise poderia aplicar-se também à igreja como um todo. Ocupada durante muito tempo em administrar as coisas do céu e da eternidade, ${ }^{11}$ a igreja esqueceu-se de dar atenção às realidades duras da vida, à política, à economia e ao social. Esqueceu-se de considerar que antes de seus congregados e congregadas entrarem na eternidade, eles e elas também vivem na terra o drama da existência humana. Trabalham e estudam, comem e vestem, adoecem e pagam suas contas. São pessoas vivas e reais, no tempo e no espaço, e devem, por assim dizer, viver plenamente aquilo que o próprio Cristo disse possibilitar aos seus: "... eu vim para que tenham vida e a tenham com abundância" (João 10.10).

O grande problema, é que a igreja assimilou na história certa dicotomia que separa os mundos. O santo e o profano. Coisas de Deus e coisas do Mundo. Algo que parece não se encontrar nas Escrituras sagradas. O que se lê são textos como este: "por que dEle, por Ele e para Ele são todas as coisas [...]" (Romanos 11.36).

De acordo com Rosino Gibellini, "separar o espaço do mundo do espaço de Cristo significa reduzir a realidade de Cristo a realidade parcial" ${ }^{12}$ Pensar assim não tem sido nada fácil para a igreja. Deve ser por isso que Bonhoeffer chamou essa proposta de "unidade polêmica".

9 Em seu $5^{\circ}$ paragráfo lê-se: “devemos partilhar o seu interesse [de Deus] pela justiça e pela conciliação em toda a sociedade humana, e pela libertação dos homens de todo tipo de opressão. Porque a humanidade foi feita à imagem de Deus, toda pessoa, sem distinção de raça, religião, cor, cultura, classe social, sexo ou idade possui uma dignidade intrínseca em razão da qual deve ser respeitada e servida, e não explorada [...] Embora a reconciliação com o homem não seja reconciliação com Deus, nem a ação social evangelização, nem a libertação política salvação, afirmamos que a evangelização e o envolvimento sóciopolítico são ambos parte do nosso dever cristão [...]". PACTO DE LAUSANNE, 1974, §5".

10 BURKE, Peter. O que é história cultural? Rio de Janeiro: Zahar, 2008. p. 148.

11 Nessa categoria de análise se encontram os grupos cristãos que em sua práxis priorizam o exercício pragmático de uma Teologia Transcendente em detrimento de uma Teologia Imanente e não desenvolvem o justo equilíbrio delas. Uma práxis que preparava o espiritual do cristão para o céu, enquanto o cristão humano padecia. O Pacto de Lausanne, estabelecido em 1974 com o objetivo de mudar tal prática da igreja cristã, propõe, através de quinze tópicos, o modelo de uma Missão Integral para Igreja.

12 GIBELLINI, 2012, p. 113. 
Neste instante faz-se necessário articular essa temática do estudo ao objeto da pesquisa no doutoramento em curso. ${ }^{13}$ Para além da investigação acerca do interesse da Assembleia de Deus pela educação através da palavra impressa, compreendendo o processo de construção identitária da cultura pentecostal, é possível perceber na vida dos primeiros crentes certo ascetismo desenvolvido em sua práxis no início da formação desta igreja.

Foi disseminada uma ética de desvalorização do mundo. Como já anunciado, uma visão dualista do sagrado e do profano constantemente interpelando os cristãos acerca de suas práticas que tendia a valorizar sempre o sagrado e desprezar o profano. As convicções provenientes de uma evolução social deveriam ser desprezadas por expressarem atitudes profanas. O crente pentecostal não procurava viver sua vida de acordo com a imanência dela, mas preocupava-se em trazer suas concepções transcendentes à imanência, objetivando assim um viver sagrado na esfera do profano, uma hierofania. A tendência era de desprezar completamente as ações exclusivas do mundo e tentar viver nele a partir de ações que promovessem, principalmente, seu bemestar espiritual. ${ }^{14}$

Esse quadro foi um reflexo da experiência religiosa e pautada no fundamentalismo doutrinário que visava exclusivamente à preparação espiritual do homem e da mulher a fim de aguardar o retorno iminente de Jesus Cristo. Os próprios líderes pioneiros demonstraram isto em sua práxis. De acordo com Francisco Rolim:

Os três missionários que lançaram entre nós o anúncio pentecostal trouxeram apenas a experiência religiosa. Não é difícil constatá-lo nos primeiros anos que aqui viveram. Gunnar Vingren e Daniel Berg em nada se interessaram pela vida do povo simples e pelas duras necessidades materiais por que este passava. Pelo que se sabe, viviam seus dias repartidos entre as horas de aprender a língua e o tempo que dedicavam às orações e leituras da Bíblia. Se reuniões faziam com os batistas, não tinham por objetivo se inteirar de como vivia o pessoal pobre que morava na periferia. [...] Sua mente estava constantemente preocupada em incutir nos batistas que os rodeavam a experiência de oração, a ponto de os pastores batistas se mostrarem um tanto apreensivos com esse tipo de comportamento: vigílias de oração noite a dentro, acompanhadas de cânticos e leitura da Bíblia. ${ }^{15}$

Como se vê, tem-se observado na gênese do movimento pentecostal uma práxis que enfatizava muito mais a experiência espiritual do crente, construindo um pragmatismo que apontava para a convicção de que tudo o mais eram coisas do mundo e

13 Título do projeto de pesquisa: "Primórdios da educação cristã na imprensa assembleiana: representações da cultura pentecostal nos jornais Boa Semente \& Mensageiro da Paz (1919-1940)".

14 FERREIRA, Ismael de Vasconcelos. Ascetismo e sectarismo no pentecostalismo clássico das Assembleias de Deus. Protestantismo em Revista, São Leopoldo, v. 39, jun./dez. 2015. p. 25-26.

15 ROLIM apud FERREIRA, 2015, p. 26. 
não dessa forma se deveria dar pouca atenção. É nesse sentido que os estudos acerca da relação da fé cristã com a sociedade podem ajudar a compreensão desse fenômeno.

Ao abordar a Teologia da Cultura, Rosino Gibellini faz referência à obra do teólogo norte-americano Richard Niebuhr, Cristo e Cultura, para apresentar seus cinco modelos de inter-relação entre cristianismo e seu contexto. São cinco tipos ${ }^{16}$ que exprimem de maneiras variadas a relação entre cristianismo e cultura, tais como transparecem no decorrer da história do cristianismo. ${ }^{17}$

Destaca-se aqui apenas o primeiro tipo, Cristo contra a cultura, que talvez não seja por acaso que ocupe essa posição, no sentido de ser o principal modelo de fé desenvolvido pelos crentes na história. O Cristo contra a cultura exprime a contraposição radical e exasperada entre natureza e graça. Tertuliano de Cartago é o exemplo típico desse posicionamento. Como não lembrar da famosa máxima de Tertuliano: “o que Atenas tem a ver com Jerusalém? Que concordância existe entre a Academia e a Igreja? E entre hereges e cristãos?". ${ }^{18}$

Tal aforismo representaria para a história da igreja a construção radical de uma dicotomia em que os "mundos" são separados. Um mundo é espiritual e tão somente necessário para ser vivido e desenvolvido por cada cristão. O outro mundo é profano e carrega consigo todas as vaidades do mundo e dele o cristão deve se separar, pois, que comunhão há entre as trevas e a luz? Assim, e por todos os séculos seguintes sempre existiu uma forte tensão entre a práxis cristã (espiritual) e o desenvolvimento de sua mente (racional). Essa dicotomia gerou a construção de um paradigma.

Para efeitos de uma contraposição, ressalta-se nesse estudo a quebra de tal paradigma como urgentemente necessário para que a igreja cumpra mais eficazmente sua missão. Não há como pensar e viver uma fé cristã dissociada de tantas outras realidades do mundo real, por assim dizer, onde diversas esferas do conhecimento e da vida dizem muito sobre Deus e sobre a humanidade em si.

Segundo Gustavo Guttierrez, "não há duas histórias, uma profana e outra sagrada, 'justapostas' ou 'estreitamente unidas', mas um só devir humano assumido irreversivelmente por Cristo, Senhor da História". ${ }^{19}$ Algo similar foi dito por Emmanuel Mounier: "rigorosamente falando, não há duas histórias estranhas uma à outra, isto é,

16 Como objetivamos aqui tratar de modo sucinto apenas o primeiro modelo, Cristo contra a cultura, segue os outros tipos. São eles: Cristo da cultura, Cristo acima da cultura, Cristo e a cultura em paradoxo e Cristo, transformador da cultura. GIBELLINI, 2012, p. 101-102.

17 GIBELLINI, 2012, p. 102.

18 OLSON, Roger. História da teologia cristã. São Paulo: Vida, 2001. p. 53.

19 GUTIÉRREZ, Gustavo. Libertação e salvação. In: GUTIÉRREZ, Gustavo. Teologia da libertação: perspectivas. São Paulo: Loyola, 2000. p. 204. 
história sagrada e profana. Há uma história apenas: a da humanidade em marcha para o Reino de Deus". ${ }^{20}$

O que Mounier afirma advém do que pode ser considerada a mais correta compreensão de visão de mundo que o cristão deveria ter. Não há esfera da realidade humana sobre a qual Deus não se importe e que Cristo não exija governo. Como disse o estadista holandês Abraham Kuyper:21 "não há um centímetro quadrado da realidade sobre o qual Cristo não possa dizer: 'É $\mathrm{Meu}^{\prime \prime \prime}{ }^{22}$

Oportunamente essa necessária práxis a ser desenvolvida pela igreja cristã, passa também por uma profunda reflexão e reavaliação do conceito de evangelização e missão. A igreja e os cristãos devem reavaliar seu entendimento sobre a missão da igreja. Se tomarem missão apenas como evangelização, a missão perderá a força, pois ela diz respeito a tudo o mais, e envolve uma cosmovisão mais ampla que aponta onde os cristãos devem atuar.

A igreja deve repensar sua atuação no mundo e seu envolvimento social deve ser parte de uma missão que não pode estar restringida as quatro paredes de um templo, nem tão pouco a tarefas puramente religiosas no sentido de não se envolver com outras demandas próprias da sociedade que inclusive dizem muito acerca das pessoas que a igreja busca evangelizar. Obviamente que neste estudo delimita-se falar de uma cosmovisão cristã em seu papel educativo, ou seja, como a educação cristã se relaciona na formação integral do seu humano.

\section{Cosmovisão cristã como práxis educacional: finalidade e missão}

Antes de apresentar em síntese a cosmovisão cristã em sua integralidade, deve-se apresentar o significado da palavra cosmovisão e articulá-la em seu sentido cristão, pois nisto se compreende também seu senso de finalidade e missão. Em um recente artigo escrito sobre o tema, foi possível apresentar algumas definições:

Apesar dessa palavra não fazer parte de nosso vocabulário diário, ela sempre foi muito usada nos meios teológicos e filosóficos. De forma simples significa: "Visão de Mundo". A visão que uma pessoa tem do mundo, do universo que a cerca, visão da própria vida. Isso é demonstrado

20 STRECK, Danilo R. Correntes pedagógicas: uma abordagem interdisciplinar. Petrópolis: Vozes/Celadec, 2005. p. 51.

21 Abraham Kuyper foi ministro da Igreja Reformada Holandesa, importante político, jornalista, estadista e teólogo holandês. Foi Primeiro-Ministro da Holanda entre 1901 e 1905. Kuyper proferiu a famosa frase em discurso inaugural da Universidade Livre de Amsterdã em 1880. Por acreditar que toda verdade vem de Deus, e que cada centímetro da criação pertence a Cristo, ele não apenas estabeleceu uma escola de teologia, mas uma universidade na qual todo o currículo, todas as artes e ciências eram parte de uma cosmovisão bíblica. Kuyper ensinou ali teologia, homilética, hebraico e literatura. FERREIRA, Franklin. Abraham Kuyper: "a minha glória não darei a outro". Disponível em: <http://www.monergismo.com/textos/biografias/kuyper_gloria.htm>. Acesso em: 07 jan. 2015.

22 LIMA, Daniel Barros de. Cosmovisão cristã: a transformação da mente cristã na contemporaneidade. Protestantismo em Revista, São Leopoldo, v. 36, jun./dez. 2015, p. 50. 
na vida prática de cada pessoa, pois aquilo que faz é fruto daquilo que ela acredita. ${ }^{23}$

Vários pensadores ao longo da história ofereceram a sua própria definição quanto ao termo cosmovisão, que teria sido cunhado e utilizado originalmente na Alemanha no período dos séculos XVIII e XIX. Na definição de Nancy Pearcey:

O termo cosmovisão é tradução da palavra alemã Weltanschauung, que significa "modo de olhar o mundo"(welt, "mundo"; schauen, "olhar") $\mathrm{O}$ romantismo alemão desenvolveu a ideia de que as culturas são conjuntos complexos nos quais certa perspectiva sobre a vida, ou o "espírito" da época, é expressa pelo painel da própria vida - na arte, literatura e instituições sociais, bem como na filosofia formal. O melhor modo de entender os produtos de qualquer cultura é entender a cosmovisão subjacente que se expressa [...]...24

Além de cosmovisão é possível encontrar autores que preferiram usar o termo biocosmovisão. Na sua definição Abraham Kuyper diz:

Tão verdadeiramente quanto cada planta tem uma raiz, do mesmo modo um princípio verdadeiramente esconde-se sob cada manifestação da vida. Estes princípios estão interligados e têm sua raiz comum num princípio fundamental; e a partir deste último é desenvolvido lógica e sistematicamente todo o conjunto de conceitos governantes e concepções que irão compor nossa vida e cosmovisão. ${ }^{25}$

Trata-se de uma compreensão de cosmovisão literalmente como uma visão ou concepção de vida e de mundo. Uma cosmovisão constitui uma perspectiva global sobre a vida que resume tudo aquilo que se sabe a respeito do mundo, como ele é avaliado emotivamente e também como se responde a ele por meio da vontade.

James Sire apresenta a seguinte definição:

Uma cosmovisão é um comprometimento, uma orientação fundamental do coração, que pode ser expressa como uma história ou um conjunto de pressuposições (hipóteses que podem ser total ou parcialmente verdadeiras ou totalmente falsas), que detemos (consciente ou subconscientemente, consistente ou inconsistentemente) sobre a constituição básica da realidade e que fornece o alicerce sobre o qual vivemos, movemos e possuímos nosso ser. 26

23 LIMA, 2015, p. 49.

24 PEARCEY, Nancy. Verdade Absoluta: libertando o cristianismo de seu cativeiro cultural. Rio de Janeiro: CPAD, 2006. p. 56.

25 KUYPER, Abraham. Calvinismo. São Paulo: Cultura Cristã, 2003. p. 198.

26 SIRE, James W. O universo ao lado: um catálogo básico sobre cosmovisão. 4. ed. São Paulo: Hagnos, 2009. p. 16. 
A partir dessa definição é possível articular seu sentido à cosmovisão cristã pelo menos em dois aspectos analíticos. O primeiro, quando o autor trata cosmovisão como orientação do coração, considerando o sentimento como primeiro motor que revela o que dizemos saber sobre as coisas a nossa volta, a despeito da ideia de que as emoções não podem ajudar a orientar seguramente a visão de mundo de uma pessoa, não obstante, este aspecto se orienta pela subjetividade. O segundo, quando apresenta essa visão de mundo como alicerce, ou seja, fundamento no qual vivemos, movemos e existimos (ontologia do ser). Esse aspecto é vivido objetivamente pelo ser humano que enxerga seu mundo pautado sobre algumas metanarrativas que podem ser defendidas plausível e racionalmente e por isso são tratadas como verdades.

Nesse sentido, e na perspectiva cristã de cosmovisão é possível articular o conceito de James Sire ao que disse o escritor bíblico Paulo de Tarso: pois nele vivemos, nos movemos e existimos, como disseram alguns dos poetas de vocês: Também somos descendência dele" (Atos 17.28). Faz-se necessário uma breve observação acerca do contexto em que Paulo expressou tal afirmação.

Paulo estava em um lugar denominado Areópago, onde habitualmente os gregos predominantemente filósofos se reuniam para ouvir discursos em que geralmente deveriam analisar e julgar questões políticas e religiosas. O Areópago era conhecido pelo senso de justiça e integridade que seus membros nutriam, pois eram sábios e magistrados.

Foi nesse ambiente, que também era um ambiente politeísta, que Paulo discorreu respeitosamente e filosoficamente acerca da fé que movia seu coração no sentido de proferir um discurso que relacionava as verdades da fé cristã como resposta às questões existenciais da vida que os próprios gregos há muito tempo se interessavam. E justamente por esse interesse, infere-se que Paulo estabeleceu em seu discurso pontos de contato com os referenciais gregos (poetas e historiadores), ao ponto de citá-los como correlações plausíveis à mensagem que ele trazia, a mensagem do Evangelho.

Essa correlação reside principalmente na afirmativa nele vivemos, nos movemos $e$ existimos, considerando que o que os gregos conjecturavam por meio de suas fontes sob determinado viés filosófico, apontava para a verdade que Paulo lhes anunciava, porém, segundo o apóstolo, faziam isso como sombra, como se estivessem tateando (analogia usada no texto) a materialidade da verdade que Paulo lhes trazia plenamente. Um conjunto de verdades as quais compunham sua mensagem formavam uma cosmovisão, a cosmovisão cristã.

Nesse ponto deve-se ressaltar que embora a cosmovisão cristã possua um conjunto de verdades, também possui como marca característica o diálogo, pois não se trata da construção de uma doutrinação intransigente e intolerante, de discursos herméticos e fechados, mas, da construção de pontes por onde as pessoas vão e vem, pois transitam 
nelas todos e todas em busca do sentido da vida, estão em busca das respostas para as mesmas questões as quais a fé cristã propõe soluções.

Nesse sentido, e apontando para a Teologia da Missão Integral, Ariovaldo Ramos afirma que todas as pessoas tentam dar solução às clássicas questões existenciais da vida, "qual é o sentido da vida, para o que é que nós existimos, de onde viemos, para onde vamos e como devemos viver? [...] dialogamos com todo mundo, inclusive com outras confissões de fé. Nós estamos lutando pela humanidade como todo mundo" ${ }^{27}$

Gleyds Domingues afirma a presença de diversas cosmovisões em nosso mundo, sendo necessário identificar as lentes usadas pelos diferentes grupos sociais pra compreendê-las. Isto é mais evidente quando há uma eleição de uma lente ou cosmovisão, visto que a partir de um conjunto de pressuposições assumidas, consciente ou inconscientemente, por um determinado grupo social, se definirá a forma como este grupo posiciona-se em relação ao cosmos. A partir disso, em seu estudo Domingues elege como objeto de investigação a cosmovisão cristã, no sentido de apresentar as bases que sustentam o seu sistema de crenças direcionadas à formação humana, que se materializa na ação educativa, a partir de uma perspectiva teorreferente. ${ }^{28}$

Neste processo, a autora estabelece como ponto de análise: a cultura, a sociedade e os valores subjacentes que se firmam na convivência social, pois estas estruturas influenciam a formação educacional de cada indivíduo. Assim, questiona-se: como a cosmovisão cristã influencia a formação humana e qual a perspectiva ética assumida neste processo educativo, uma vez que a proposta educacional não apenas delineia os rumos do processo ensino e aprendizagem, mas elenca princípios e objetivos a serem perseguidos em prol da finalidade eleita? Porém, a perspectiva assumida sinaliza para uma relação a ser estabelecida entre homens e mulheres, o que indica a presença de uma visão interrelacional, e não egocêntrica e individualizada, mas cooperativa e solidária. ${ }^{29}$

De acordo com Rodolfo de Souza, a cosmovisão pode ser pensada como um mapa que "funcionaria como um compasso ou um mapa, que nos orientaria quanto ao mundo em geral, dando-nos sentido do que está certo ou errado na confusão dos eventos e fenômenos que confrontamos, afetando a forma como acessamos os eventos da vida" ${ }^{30}$

Gleyds Domingues se apóia na ideia de mapa, pois com um mapa se cria marcos de coordenadas possibilitando a quem o usa a sensação de segurança, confiança e estabilidade. Um mapa indica a presença de fronteiras e de espaço conquistado, o que

27 RAMOS, Ariovaldo. A teologia da missão integral e o marxismo. Revista Ultimato. Disponível em: <http:/ / www.ultimato.com.br/conteudo/marxismo-e-missao-integral>. Acesso em: 21 jun. 2016.

28 DOMINGUES, Gleyds Silva. A proposta da cosmovisão cristã, a formação humana e a ética no processo educativo. Revista Teologia e Espiritualidade, Curitiba, n. 4, out. 2014. p. 2.

29 DOMINGUES, 2014, p. 3-5.

30 SOUZA, Rodolfo Amorim Carlos de. Cosmovisão: evolução do conceito e aplicação cristã. In: LEITE, Claudio Antônio Cardoso; CARVALHO, Guilherme Vilela Ribeiro de; CUNHA, Maurício José Silva (Orgs.). Cosmovisão cristã e transformação. Viçosa: Ultimato, 2006. p. 41. 
assegura movimento e dinamicidade, podendo fazer com que grupos específicos convivam com outras cosmovisões sem se sentirem ameaçados. ${ }^{31}$ Embora, afirma-se que invariavelmente estamos todos num campo de luta pela melhor cosmovisão.

Pensa-se que por causa dessa característica do diálogo a própria cosmovisão cristã esteja sempre sofrendo melhoramentos. Assim, a educação encaminhada pela cosmovisão cristã envolve mudança de mentalidade. Uma mentalidade que adquira forma e conteúdo. ${ }^{32} \mathrm{E}$ se o ponto de partida da cosmovisão realmente for Cristo, deve-se viver essa práxis olhando para as palavras e atitudes de Jesus e não apenas agir como Jesus, mas pensar como ele pensa. Assim, afirma-se que:

O entendimento dessa cosmovisão cristã considera necessária a reavaliação do comportamento e influência cultural, recebidos pelas principais instituições humanas, o estado, a igreja e a família, que estabelecem padrões de comportamentos, dentre os quais devem ser percebidos àqueles que podem estar equivocados ante ao padrão das Escrituras. ${ }^{33}$

Nancy Pearcey, que defende uma necessária libertaçao do cristianismo de seu cativeiro cultural, também fala sobre o processo de transformação da mente cristã em busca de uma cosmovisão cristã mais próxima do caráter de Cristo dizendo que:

Se nosso propósito é ter a mente de Cristo, devemos primeiro estar dispostos a nos submeter ao padrão de sofrimento que Ele modelou para nós. Devemos estar na expectativa de que o processo de desenvolvimento de uma cosmovisão cristã é uma luta árdua e dolorosa; primeiro interiormente, ao desarraigarmos os ídolos de nosso padrão de pensamento, e depois exteriormente, ao enfrentarmos a hostilidade de um mundo caído e descrente. ${ }^{34}$

A força de cada cristão para cumprir essa missão deve vir da união espiritual com Cristo, reconhecendo que o sofrimento é a rota principal para se conformar à Sua imagem. Assim, é possível fazer uma diferença significativa de influência em quaisquer esferas de atuação pública, aqui especialmente no campo da educação, tendo em mente que crucificar a apetência pelo sucesso, poder e aclamação pública podem trazer sobre cada educador e educadora a satisfação de ser mais parecido com Cristo.

De acordo com Gleyds Domingues, a proposta educacional na cosmovisão cristã visa à formação do sujeito integral, à medida que envolve todas as dimensões do ser

31 DOMINGUES, 2014, p. 7.

32 De acordo com Rinald Jr. a proposta educacional deve ser permeada pela excelência em três níveis: excelência no ser; excelência no saber; excelência no fazer. O ser humano é afetado pela maneira de ser, saber e fazer. RINALDI JR., Roberto. Educação na perspectiva cristã: uma reflexão sobre essa abordagem e seu impacto na família, igreja, escola e nação. Belo Horizonte: AECEP, 2012. p. 10.

33 LIMA, 2015, p. 48.

34 PEARCEY, 2005, p. 37. 
humano: física, cognitiva, afetiva, laboral e espiritual. Assim, não há como falar de prática educativa dissociada dos relacionamentos, da alteridade, da visão do outro. Além do próprio sujeito, a visão a ser compartilhada envolve sempre a presença do outro. A prática educativa tem uma finalidade relacional e é por isso que esta se concretiza na vida em comunidade. ${ }^{35}$

Uma vez compreendia a finalidade educacional na cosmovisão cristã, destaca-se a presença da ética ${ }^{36}$ como um dos elementos fundamentais da base de uma cosmovisão, então tem-se seu sentido de missão. Nessa função, a cosmovisão cristã visa responder as questões essenciais sobre a existência do todo o cosmos, natureza e humanidade. Questões da vida, desde as mais simples até as mais complexas que envolvem o ser humano como todo. Esse ethos estabelece um padrão de moralidade que pode nortear a conduta de homens e mulheres no contexto da sociedade.

Embora este estudo não tenha a pretensão de aprofundar as discussões éticas, as quais geralmente estão envoltas a muitas controvérsias, o que se anuncia aqui é de extrema relevância, pois a ética numa perspectiva cristã desenvolve princípios norteadores que consideram a vida, a moralidade e a condição humana a partir da revelação bíblica no sentido de ser e existir para cumprir uma missão em prol da transformação das pessoas na sociedade e se espera como resultado que possa afetar profundamente as próximas gerações nos melhoramentos que a educação cristã propõe fazer. Isso passa pela necessária formação de bons educadores e educadoras que poderão influenciar futuras gerações numa visão cíclica e contínua, pois conforme diz Gleyds Domingues, "este é o papel da educação no processo de construção e afirmação de novas mentalidades". 37

Oportunamente, pode-se concluir essa compreensão e pontual exposição acerca do caráter missional da cosmovisão cristã refletindo no que Maria José Lima observa como preponderante nessa missão, apontando para um novo comportamento dos jovens cristãos no espaço público:

Portanto, eles entrarão nos diversos espaços da sociedade cônscios de quê, como representantes do Reino de Deus na terra, precisarão dominar sua linguagem, seus princípios e seus valores, de tal forma que estes serão a força que os motivará a atuarem neste mundo como cérebros pensantes, inteligentes, não apenas como religiosos. Uma cosmovisão poderosa que afetará todas as áreas de sua vida. É claro que nem todos os jovens cristãos

35 DOMINGUES, 2014, p. 9.

36 Conforme Gleyds Domingues, "a aplicação do conceito da ética pode seguir duas vertentes: teleológica ou deontológica, isso indica que a vertente assumida possibilitará compreender a maneira como homens e mulheres se posicionam sobre os temas evidenciados na realidade social [...]". DOMINGUES, 2014, p. 9. Na vertente teleológica, a regra é determinada pelos resultados. O aforismo de Nicolau Maquiavel ilustra bem essa vertente, os fins justificam os meios. Na vertente deontológica, os resultados são determinados pela regra. Nessa vertente, os princípios são fundamentais para os fins. A perspectiva da cosmovisão cristã assume a ética deontológica.

37 DOMINGUES, 2014, p. 13. 
necessariamente serão teólogos de formação. Mas, em cada profissão escolhida por eles, serão capazes de levar o conhecimento substancial da Teologia Bíblica, que será o diferencial na atuação de cada um deles em suas profissões. Serão advogados, médicos, engenheiros, administradores, jornalistas, pedagogos, psicólogos, historiadores, sociólogos, matemáticos, físicos, profissionais liberais, enfim, convictos de quem são em Cristo, fazendo tudo para a Glória de Deus! 38

Nessa direção, pode-se afirmar que o caráter missional da igreja no campo educacional encontra significado e cumpre seu propósito. Alguns textos bíblicos passam a ter todo sentido. E tudo o que fizerdes, seja em palavra, seja em ação, fazei-o em nome do Senhor Jesus, dando por ele graças a Deus Pai (Colossenses 3.17). Porque dEle, e por meio dEle, e para Ele são todas as coisas. A Ele, pois, a glória eternamente. Amém! (Romanos 11.36). O pensamento do estadista holandês Abraham Kuyper amplia ainda mais essa convicção:

[...] Cristo é Rei em cada departamento da vida e a atividade humana era a diretriz que ele manteve soando em todos os seus escritos, discursos e labores. Quer como teólogo ou como estadista, como um líder na política, como presidente do sindicato cristão, como promotor da educação cristã, tudo foi feito com a ardente convicção de que: Cristo governa não simplesmente pela tradição do que ele outrora foi, falou, fez e suportou; mas por um poder vivo que ainda agora, assentado como ele está à mão direita de Deus, exerce sobre terras e nações, gerações, famílias e indivíduos. 39

Portanto, essa convicção deve mover a práxis de cada educador e a educadora cristã, compreendendo que, mais do que cargos e títulos, possuem um encargo nobre e um chamado divino para tocarem nas pessoas e alterarem significativamente o curso de suas vidas, e por conseguinte podem contribuir para uma nação toda pode ser transformada. Esse é o maior título do educador e da educadora, servir a todos e todas indiscriminadamente aonde quer que estejam.

\section{Considerações finais}

Este estudo tratou de modo introdutório da educação integral na perspectiva da cosmovisão cristã. Observou-se que não são poucos educadores que vêm se preocupando com a recuperação de um sentido mais amplo e abrangente de educação. Foi possível perceber que uma educação que contemple o ser humano como um todo pode correlacionar-se aos princípios norteadores da educação cristã, pois fornece subsídios de uma visão de mundo que contempla todas as dimensões do ser humano como possíveis de serem observadas pelas Escrituras Sagradas.

38 LIMA, Maria José Costa. Um enigma de Deus: a história de um legado de fé e educação. Manaus: Travessia, 2015. 194.

39 KUYPER, 2002, p. 14. 
A igreja pode ser desafiada com esta reflexão e buscar ressignificar sua práxis sempre. Especialmente o movimento pentecostal na efervescência dos anos de seu centenário vem buscando alterar significativamente a maneira como tratou as demais esferas da vida (e não apenas a espiritual), pois desde sua gênese desenvolveu uma práxis cristã que defendia um Cristo contra Cultura como modelo ideal de seu ethos. Porém, como disse certa feita John Cobb, “o cristianismo é processo, é movimento e o é ainda agora; conserva, pois, a capacidade de corrigir-se e renovar-se" ${ }^{40}$ Dessa forma, já é possível perceber nas igrejas provenientes do próprio pentecostalismo clássico uma preocupação com a educação cristã e a educação formal, e ver nelas imbuída a integralidade da educação que constrói um novo discurso, onde a fé possui uma práxis simultaneamente transcendente e imanente.

Como não lembrar nesse instante da máxima de Gottfried Brakemeier, quando disse que "o ser humano experimenta Deus 'em, com e sob' as coisas deste mundo". ${ }^{41}$ Enquanto lida-se com as contingências próprias desse mundo, e mais do que isso, quando a própria condição humana do nosso tempo se depaupera sobre nós, é possível a igreja interferir diretamente na transformação da mesma, e perceber Deus a todo instante.

Portanto, conclui-se este estudo com a compreensão de que uma cosmovisão impacta a forma de ser e agir dos grupos sociais. Em seu interior homens e mulheres tecem leituras sobre a realidade e são assim guiados por elas. A cosmovisão cristã considera o ser humano em sua integralidade. Todos e todas são sujeitos ativos de um processo de transformação da mente e devem pensar e agir com a base teorreferente sob uma perspectiva integralmente ética e bíblica.

\section{Referências}

BRAKEMEIER, Gottfried. Panorama da Dogmática Cristã. São Leopoldo: Sinodal/EST, 2010.

BURKE, Peter. O que é história cultural? Rio de Janeiro: Zahar, 2008.

CAMARGO, Thiago Dutra de. Educação integral e espiritualidade: os benefícios dessa relação para a formação integral do ser humano. Porto Alegre: EDUFRGS, 2015.

YUS, Rafael. Educação integral: uma educação holística para o século XXI. Porto Alegre: Artmed, 2002.

DOMINGUES, Gleyds Silva. A proposta da cosmovisão cristã, a formação humana e a ética no processo educativo. Revista Teologia e Espiritualidade, Curitiba, n. 4, out. 2014.

FERREIRA, Franklin. Abraham Kuyper: “a minha glória não darei a outro”. Disponível em: <http://www.monergismo.com/textos/biografias/kuyper_gloria.htm>. Acesso em: 07 jan. 2015.

40 GIBELLINI, 2012, p. 424.

41 BRAKEMEIER, Gottfried. Panorama da Dogmática Cristã. São Leopoldo: Sinodal/EST, 2010. p. 34. 
FERREIRA, Ismael de Vasconcelos. Ascetismo e sectarismo no pentecostalismo clássico das Assembleias de Deus. Protestantismo em Revista, São Leopoldo, v. 39, jun./dez. 2015.

GIBELLINI, Rosino. A teologia do Século XX. São Paulo: Loyola, 2012.

GUTIÉRREZ, Gustavo. Libertação e salvação. In: GUTIÉRREZ, Gustavo. Teologia da libertação: perspectivas. São Paulo: Loyola, 2000.

KUYPER, Abraham. Calvinismo. São Paulo: Cultura Cristã, 2003.

LIMA, Daniel Barros de. Cosmovisão cristã: a transformação da mente cristã na contemporaneidade. Protestantismo em Revista, São Leopoldo, v. 36, jun./dez. 2015.

LIMA, Maria José Costa. Um enigma de Deus: a história de um legado de fé e educação. Manaus: Travessia, 2015.

OLSON, Roger. História da teologia cristã. São Paulo: Vida, 2001.

PACTO DE LAUSANNE. Disponível em: <http://www.lausanne.org/pt-br/>. Acesso em: 08 jul. 2015.

PEARCEY, Nancy. Verdade Absoluta: libertando o cristianismo de seu cativeiro cultural. Rio de Janeiro: CPAD, 2006.

RAMOS, Ariovaldo. A teologia da missão integral e o marxismo. Revista Ultimato.

Disponível em: <http:/ / www.ultimato.com.br/conteudo/marxismo-e-missao-integral>. Acesso em: 21 jun. 2016.

RINALDI JR., Roberto. Educação na perspectiva cristãa: uma reflexão sobre essa abordagem e seu impacto na família, igreja, escola e nação. Belo Horizonte: AECEP, 2012.

SIRE, James W. O universo ao lado: um catálogo básico sobre cosmovisão. 4. ed. São Paulo: Hagnos, 2009.

SOUZA, Rodolfo Amorim Carlos de. Cosmovisão: evolução do conceito e aplicação cristã. In: LEITE, Claudio Antônio Cardoso; CARVALHO, Guilherme Vilela Ribeiro de; CUNHA, Maurício José Silva (Orgs.). Cosmovisão cristã e transformação. Viçosa: Ultimato, 2006.

STRECK, Danilo R. Correntes pedagógicas: uma abordagem interdisciplinar. Petrópolis: Vozes/Celadec, 2005.

VV.AA. Tendências para a educação integral. São Paulo: Fundação Itaú Social - CENPEC, 2011. 